\title{
MENDETEKSI PERILAKU FRAUD LAPORAN KEUANGAN DENGAN THEORY OF PLANNED BEHAVIOR (STUDI EMPIRIS PADA INDUSTRI PERBANKAN)
}

\author{
Lieani Christina \\ Septian Bayu Kristanto* \\ Universitas Kristen Krida Wacana, Jalan Tanjung Duren Raya no. 4, Grogol Petamburan, Jakarta Barat, 11470 \\ *septian.bayu@ukrida.ac.id
}

\author{
A R T I C L E I N F O \\ Article history: \\ Received October 12, 2018 \\ Revised November 08, 2018 \\ Accepted November 20, 2018
}

Key words:

Fraud, Behavior, Auditor, Attitude, Financial Statements

\begin{abstract}
A B S T R A C T
This study aim to examine factors that determined the intention towards fraud in financial statements in banking industry. Based on UU Perbankan No. 10 tahun 1998, banking industry are perceived to be safeguarded from fraud occurrences. On the other side, this study intends to examine the relevance of the theory of planned behavior in measuring intention and behavior towards fraud. A total of 158 questionnaires were collected. Structural equation modelling was used to test the model. The Findings indicates that attitude, subjective norms, and perceived behavioral control are influenced intention to fraud financial statements with R2 value 0.92. Thus, intention influenced behavior with $R 2$ value 0.89 . This study proved that if respondents are favor of financial statements fraud, so their intention strongly committed to financial statements fraud. Therefore, more positive intention to commit fraud leads behavior in financial statement fraud.
\end{abstract}

\begin{abstract}
A B S T R A K
Penelitian ini bertujuan untuk menguji faktor-faktor yang menentukan niat terhadap kecurangan dalam laporan keuangan di industri perbankan. Berdasarkan UU Perbankan No. 10 tahun 1998, industri perbankan dianggap sebagai pelindung dari kejadian kecurangan. Di lain sisi, penelitian ini bermaksud untuk menguji relevansi theory of planned behavior dalam mengukur niat dan perilaku terhadap kecurangan. Sebanyak 158 kuesioner dikumpulkan. Structural equation modelling (SEM) digunakan untuk menguji model. Temuan menunjukkan bahwa attitude, subjective norms, and perceived behavioral control yang dirasakan dipengaruhi niat untuk kecurangan atas laporan keuangan dengan nilai R2 0,92. Dengan demikian, niat mempengaruhi perilaku mempunyi nilai $R 2$ 0,89. Penelitian ini membuktikan bahwa jika responden menyukai kecurangan atas laporan keuangan, maka niat mereka sangat kuat terhadap kecurangan atas laporan keuangan. Oleh karena itu, semakin positif niat untuk melakukan kecurangan akan mengarah pada perilaku dalam kecurangan atas laporan keuangan.
\end{abstract}

\section{PENDAHULUAN}

Kasus fraud merupakan kasus yang masih terus bergulir dari waktu ke waktu. Berdasarkan data laporan The 2016 Report to the Nations on Occupational Fraud and Abuse, tercatat ada 2.410 kasus fraud yang tersebar di 114 negara di seluruh dunia dengan total kerugian mencapai \$6.300.000 (Association of Certified Fraud Examiners, 2016). Dalam laporan tersebut juga menyatakan korupsi merupakan tipe kasus fraud tertinggi di setiap negara, salah satu diantaranya adalah di AsiaPasifik. Ada 107 kasus yang berkaitan dengan korupsi, yaitu sekitar $48,4 \%$ dari total kasus fraud yang ada di Asia-Pasifik (ACFE, 2016). Ditinjau dari jenis indrustrinya, kasus fraud terbanyak ter- dapat pada industri perbankan dan jasa keuangan dengan total 368 kasus atau 16,8\% dari total kasus fraud di dunia. Dari 368 kasus yang terjadi di industri perbankan, 138 diantaranya merupakan kasus korupsi (ACFE, 2016).

Fraud terjadi diberbagai industri, mulai dari industri manufaktur, real estate, minyak dan gas, bahkan tidak terkecuali pada industri dengan regulasi paling ketat, yaitu perbankan dan jasa keuangan. Berdasarkan data dari ACFE 2016, peneliti berkeinginan untuk mengkaji berbagai faktor yang mempengaruhi individu untuk melakukan fraud terutama pada industri perbankan. Beberapa kasus terkait tindak kejahatan pada industri perbankan juga dinilai sebagai salah satu indikator hilangnya 
rasa aman terhadap industri dengan regulasi yang ketat sekalipun.

Berbagai kasus fraud yang terjadi di Indonesia beberapa tahun silam menunjukkan bahwa industri dengan peraturan yang ketat sekalipun tidak menjamin terciptanya keamanan yang memadai untuk meredam terjadinya fraud. Salah satu contoh kasus fraud yang terjadi pada industri perbankan yaitu kasus penggelapan dana nasabah Bank Citibank oleh Senior Relationship Manager, Malinda Dee. Kasus yang terjadi pada tahun 2012 ini termasuk dalam kategori tindak pidana perbankan yang melanggar UU No. 10 tahun 1998 tentang Perbankan dan tindak pidana pencucian uang yang melanggar UU No. 25 tahun 2003 tentang Tindak Pidana Pencucian Uang (More, 2012).

Menurut Siti dkk. (2011), theory of reasoned action digunakan dalam penelitiannya untuk mengukur niat perilaku individu melakukan fraud dalam laporan keuangan berdasarkan keyakinan perilaku dan keyakinan normatif. Hasilnya menunjukkan kedua konstruk tersebut mempengaruhi niat seseorang untuk melakukan fraud dalam laporan keuangan. Berdasarkan kesimpulan tersebut, theory of reasoned action dinilai cukup sukses untuk menjelaskan niat perilaku dalam melakukan kecurangan laporan keuangan.

Dengan pendekatan yang berbeda, penelitian yang dilakukan oleh Carpenter dan Reimers (2005) mengukur perilaku seseorang dengan theory of planned behavior menunjukkan hasil yang hampir serupa, dimana sikap perilaku manajer dan norma subyektif secara signifikan mempengaruhi niat perilaku manajer dalam pengambilan keputusan yang etis. Pentingnya pengambilan keputusan yang etis sangat diperlukan dalam penyusunan laporan keuangan untuk menghindari bias dalam penyajian laporan keungan.

Menurut Awang dkk. (2015) industri perbankan merupakan salah satu industri dengan regulasi yang paling ketat. Hal tersebut menjadikan industri perbankan wajib memberikan jaminan rasa aman bagi para nasabahnya untuk bebas dari terjadinya fraud. Serupa dengan kondisi yang ada di negara lain, saat ini industri perbankan di Indonesia pun merupakan industri dengan regulasi yang paling ketat dibandingkan dengan industri lainnya. Meskipun demikian, kasus fraud pada industri perbankan masih saja terjadi di Indonesia. Oleh karena itu, perlu adanya analisis untuk mengukur potensi terjadinya fraud pada industri perbankan dengan berfokus pada pelaku fraud itu sendiri.

Menurut Stone dkk. (2009) memprediksi berbagai perilaku individu merupakan tujuan utama dari model theory of planned behavior. Oleh karena itu, konstruk intention dipercaya dapat memprediksi behavior individu untuk melakukan suatu tindakan tertentu. Dalam penelitiannya tentang academic misconduct, dinyatakan baik intention maupun justification keduanya secara signifikan terkait dengan perilaku menyontek.

Pada penelitian ini, peneliti akan meneliti kembali penelitian yang dilakukan oleh Awang dkk. (2015), namun dalam penelitian ini pendekatan yang digunakan adalah theory of planned behavior. Selain itu, sampel yang digunakan dalam penelitian ini adalah industri perbankan yang ada di Indonesia. Permasalahan yang timbul dalam penelitian ini adalah:

1. Apakah attitude dapat mempengaruhi intention untuk melakukan fraud dalam laporan keuangan bank?

2. Apakah subjective norms dapat mempengaruhi intention untuk melakukan fraud dalam laporan keuangan bank?

3. Apakah perceived behavioral control dapat mempengaruhi intention untuk melakukan fraud dalam laporan keuangan bank?

4. Apakah intention dapat mempengaruhi behavior untuk melakukan fraud dalam laporan keuangan bank?

Tujuan dari penelitian ini adalah untuk:

1. Menemukan bukti empiris pengaruh attitude terhadap intention untuk melakukan fraud dalam laporan keuangan bank.

2. Menemukan bukti empiris pengaruh subjective norms terhadap intention untuk melakukan fraud dalam laporan keuangan bank.

3. Menemukan bukti empiris pengaruh perceived behavioral control terhadap intention untuk melakukan fraud dalam laporan keuangan bank.

4. Menemukan bukti empiris pengaruh intention terhadap behavior untuk melakukan fraud dalam laporan keuangan bank.

Peneliti melalui penelitian ini bermaksud untuk menguji relevansi theory of planned behavior yang telah dikembangkan oleh Ajzen (1991). Selain itu, penelitian ini diharapkan dapat memperkaya literatur tentang fraud laporan keuangan terutama dalam analisis perilaku para pelaku fraud. Melalui penelitian ini, diharapkan dapat bermanfaat bagi 
industri perbankan untuk meningkatkan regulasi dan penanaman nilai-nilai etika pada seluruh karyawan untuk meredam terjadinya fraud di masa yang akan datang.

\section{KAJIAN LITERATUR DAN PENGEMBANGAN HIPOTESIS}

\section{Theory of Planned Behavior}

Theory of Planned Behavior merupakan hasil dari pengembangan Theory of Reasoned Action. Dalam theory of planned behavior ada satu konstruk tambahan yaitu perceived behavioral control. Dengan munculnya konstruk tambahan ini berarti intention individu untuk melakukan suatu perilaku tidak hanya dipengaruhi oleh attitude dan subjective norms, seperti yang dinyatakan dalam theory of reasoned action sebelumnya (Ajzen, 1991).

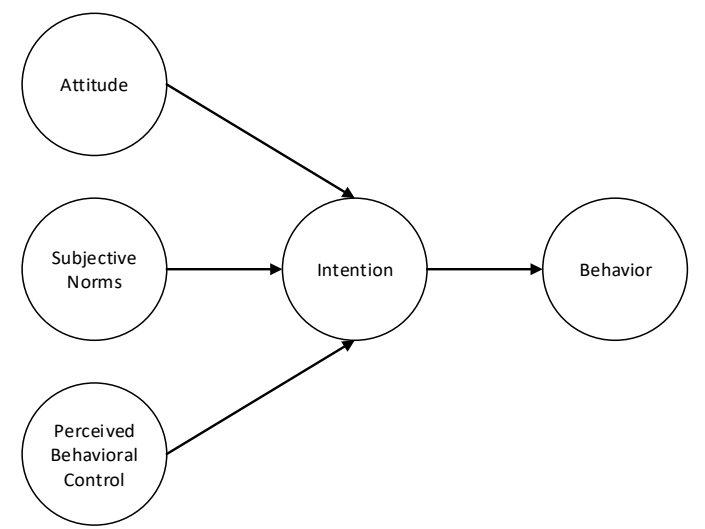

Gambar 1. Theory of Planned Behavior by Ajzen Sumber: Ajzen (1991)

\section{Financial Statement Fraud}

Pengertian fraud sesuai dengan Standar Profesional Akuntan Publik No. 70 adalah salah saji atau penghilangan secara sengaja jumlah atau pengungkapan dalam laporan keuangan untuk mengelabui pemakai laporan keuangan. Adapun unsur-unsur fraud diantaranya: terdapat kesalahan pernyataan, terjadi pada masa lampau atau saat ini, adanya fakta yang bersifat material, terjadi karena disengaja atau tanpa perhitungan, dan adanya kesaksian pihak yang dirugikan. Menurut Association of Certified Fraud, ada 3 kategori fraud yang sering disebut Fraud Tree, yaitu, fraud terhadap aset (misappropriations assets), fraud pada laporan keuangan (financial statement fraud), dan korupsi (corruption)(ACFE, 2016).

Dari ketiga kategori fraud yang ada, penelitian ini akan berfokus pada jenis fraud kedua yaitu fraud pada laporan keuangan (financial statement fraud). Fraud pada laporan keuangan ini dapat berupa manipulasi terhadap laporan keuangan yang bisa membuat net income menjadi overstated atau understated. Berbagai teknik yang dapat digunakan untuk memanipualasi laporan keuangan diantaranya, adanya pengakuan pendapatan yang tidak sah, pengurangan beban dan utang, penilaian aset yang tidak benar, pengungkapan yang tidak sah, dan berbagai teknik lainnya (ACFE, 2016).

\section{Intention untuk melakukan financial statement fraud}

Dalam penelitian ini, model yang digunakan untuk mengukur niat individu untuk melakukan financial statementfraud yaitu dengan menggunakan salah satu konstruk dari theory of planned behavior, salah satunya adalah intention. Intention adalah probabilitas sebagai dasar bagi seseorang atau subjek yang akan membentuk perilaku (Siti dkk.,2011). Intention akan mempengaruhi perilaku aktual seseorang untuk melakukan fraud atau tidak. Dengan timbulnya niat untuk melakukan fraud maka kemungkinan besar seseorang akan melakukannya sebagai bentuk perilaku aktual atas niat untuk melakukan fraud.

Penelitian mengenai perilaku yang berkaitan dengan financial statement fraud pernah dilakukan sebelumnya oleh Carpenter dan Reimers (2005) disebutkan bahwa tujuan utama penggunaan theory of planned behavior adalah untuk memprediksi dan menjelaskan perilaku individu, melalui variabel intention untuk melakukan financial statement fraud.

\section{Attitude}

Attitude berperan sebagai salah satu faktor yang dapat mempengaruhi intention. Attitude merupakan sebuah evaluasi atau penilaian terhadap baik atau buruknya suatu perilaku. Attitude juga merupakan bagian dari fungsi keyakinan perilaku. Attitude seringkali dianggap sebagai prediktor utama dalam memprediksi perilaku seseorang, atau dapat dikatakan sebagai variabel dengan korelasi yang paling kuat daripada kedua variabel lainnya (Winahjoe dan Sudiyanti, 2014).

\section{Subjective Norms}

Subjective norms merupakan persepsi tekanan untuk melakukan atau tidak melakukan suatu perilaku. Tekanan ini dapat berasal dari teman, keluarga, rekan kerja, atasan, atau pemegang kepentingan lainnya. Subjective norms berfokus pada pentingnya persetujuan atas suatu perilaku yang berasal dari pihak luar (Hays, 2013). 


\section{Perceived Behavioral Control}

Theory of planned behavior adalah pengembangan dari theory of reasoned action. Munculnya persepsi perceived behavioral control merupakan konstruk tambahan sebagai hasil dari pengembangan theory of reasoned action. Perceived behavioral control merupakan kemampuan atau persepsi seseorang untuk mengendalikan suatu perilaku (Rustiarini dan Sunarsih, 2015).

\section{Behavior}

Behavior merupakan tindakan yang dilakukan berdasarkan intention individu. Semakin besar dukungan attitude dan subjective norms maka semakin kuat intention seseorang untuk melakukan suatu perilaku. Selain itu, semakin besar perceived behavioral control yang dirasakan, maka semakin kuat intention seseorang untuk melakukan suatu perilaku tertentu (Rustiarini dan Sunarsih, 2015).

\section{Tipe Bank}

Pada penelitian ini, tipe bank dibedakan menjadi dua, yaitu bank syariah (Islamic Bank) dan bank konvensional (Conventional Bank). Bank syariah merupakan bank yang dipercaya memiliki identitas etis dalam menjalankan filosofi bisnis yang berlandaskan nilai-nilai agama. Prinsip utama dalam kegiatan dan aktivitas operasi dari bank syariah adalah hukum Shari'ah Islami'iah, sedangkan bank konvensional menjalankan kegiatan operasinya tanpa adanya aspek keagamaan (Haniffa dan Hudaib, 2007).

\section{Penelitian Sebelumnya}

Beberapa penelitian sebelumnya terkait fraud dengan pendekatan theory of planned behavior telah dilakukan. Penelitian yang dilakukan oleh Carpenter dan Reimers (2005) ini menggunakan 2 metode yaitu survey analysis dan experimental analysis untuk menguji pengaruh attitude, subjective norms, perceived behavioral control, terhadap intention manajer untuk melanggar GAAP dalam rangka mengejar target dan mendapat bonus. Penelitian ini menyimpulkan bahwa theory of planned behavior dapat memberikan bukti yang kuat dalam menjelaskan perilaku manajer saat pengambilan keputusan yang etis.

Penelitian yang dilakukan oleh Winahjoe dan Sudiyanti (2014) dalam menguji niat mahasiswa fakultas ekonomi dan bisnis di Universitas Gadjah Mada, untuk bertindak tidak etis seperti: meminta teman untuk tanda tangan di daftar hadir kelas, menyontek saat ujian, melakukan tindakan plagiarisme. Hasilnya menunjukkan attitudemerupakanpredictorterkuat dalam memprediksi niat mahasiswa untuk melakukan tindakan tidak etis. Kemudian diposisi kedua ada perceived behavioral control yang juga memiliki pengaruh cukup kuat dalam memprediksi niat mahasiswa untuk melakukan tindakan tidak etis.

Dengan pendekatan theory planned behavior dan cheating justifications, Stone dkk. (2009) melakukan penelitian untuk memprediksi academic misconduct. Hasilnya, baik attitude, subjective norms, dan perceived behavioral control sangat terkait dengan perilaku menyontek. Academic misconduct dapat diminimalisir dengan membentuk sikap untuk tidak menyontek, mengubah persepsi norma subjektif mengenai prevelansi kecurangan, dan menurunkan persepsi kontrol perilaku menyontek.

Penelitian lain yang dilakukan oleh Rustiarini dan Sunarsih (2015) terkait fraud dan whistleblowing dengan menggunakan pendekatan theory of planned behavior pada auditor pemerintah yang bekerja di BPK dan BPKP Bali. Hasil penelitian ini menunjukkan variabel perceived behavioral control memiliki pengaruh signifikan terhadap intention untuk melakukan whistleblowing, sedangkan variabel attitude dan subjective norms tidak memiliki pengaruh terhadap intention untuk melakukan whistleblowing.

Dengan pendekatan yang berbeda, penelitian yang dilakukan Awang dkk. (2015) menggunakan theory of reasoned action terkait perilaku fraud yang dilakukan oleh akuntan perbankan. Hasil penelitian tersebut menyimpulkan bahwa ada dua faktor yang mempengaruhi intention akuntan bank untuk melakukan fraud yaitu attitude dan subjective norms.

\section{Pengembangan Hipotesis}

Hubungan antara attitude dengan intention

Dalam penelitian yang dilakukan oleh Winahjoe dan Sudiyanti (2014) attitude mempengaruhi intention lebih kuat dibandingkan dengan dua konstruk lainnya. Peneliti akan menguji kembali hubungan antara attitude dengan intention. Berdasarkan hasil pengujian penelitian sebelumnya, maka dapat dirumuskan hipotesis pertama dalam penelitian ini yaitu:

$\mathrm{H}_{1}$ : Attitude memiliki pengaruh positif terhadap intention untuk melakukan fraud.

\section{Hubungan antara subjective norms dengan intention}

Stone dkk. (2009) menyatakan dalam penelitiannya subjective norms mempengaruhi inten- 
tion terkait perilaku siswa dalam melakukan academic misconduct. Peneliti akan menguji kembali hubungan antara subjective norms dengan intention.Berdasarkan hasil pengujian penelitian sebelumnya, maka dapat dirumuskan hipotesis pertama dalam penelitian ini yaitu:

$\mathrm{H}_{2}$ : Subjective norms memiliki pengaruh positif terhadap intention untuk melakukan fraud.

Hubungan antara perceived behavioral control dengan intention

Rustiarini dan Sunarsih (2015) dalam penelitiannya menyebutkan bahwa perceived behavioral control memiliki hubungan yang positif signifikan terhadap intention. Peneliti akan menguji kembali hubungan antara perceived behavioral control dengan intention.Berdasarkan hasil pengujian penelitian sebelumnya, maka dapat dirumuskan hipotesis pertama dalam penelitian ini yaitu:

$\mathrm{H}_{3}$ : Perceived behavioral control memiliki pengaruh positif terhadap intention untuk melakukan fraud.

Hubungan antara intention dengan behavior

Penelitian yang dilakukan oleh Stone dkk. (2009) menyatakan bahwa terdapat hubungan yang terkait satu sama lain antara student intention terhadap cheating behavior. Peneliti akan mnguji kembali hubungan antara intention dengan behavior. Berdasarkan hasil pengujian penelitian sebelumnya, maka dapat dirumuskan hipotesis pertama dalam penelitian ini yaitu:

$\mathrm{H}_{4}$ : Intention memiliki pengaruh positif terhadap behavior untuk melakukan fraud.

\section{$\underline{\text { Rerangka Penelitian }}$}

Penelitian ini merupakan replikasi dari penelitian yang dilakukan oleh Awang dkk. (2015) tentang mengukur potensi terjadinya financial reporting fraud di industri perbankan di Malaysia dengan pendekatan theory of reasoned action. Dengan menggunakan pendekatan yang berbeda, peneliti menggunakan theory of planned behavior dan menggunakan sampel yang ada di Indonesia, khususnya di wilayah DKI Jakarta. Seluruh konstruk yang ada di penelitian sebelumnya akan digunakan kembali dengan satu konstruk tambahan yaitu perceived behavioral control.

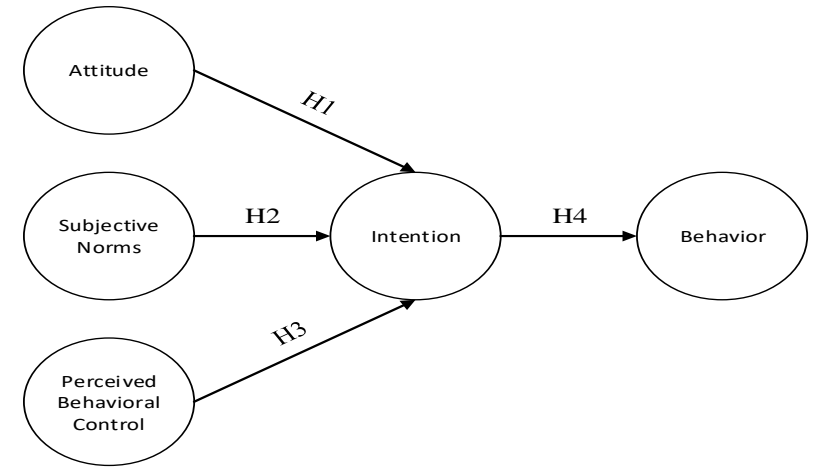

Gambar 2. Skema Rerangka Pemikiran

\section{METODE PENELITIAN}

Jenis dan Sumber Data

Penelitian ini termasuk dalam penelitian dengan jenis data kuantitatif, karena diperlukan adanya pengujian secara statistik dalam penelitian ini. Sumber data yang digunakan dalam penelitian ini adalah data primer yaitu data yang diperoleh secara langsung dari sumbernya (responden). Data primer akan dikumpulkan melalui kuesioner yang berisi pernyataan-pernyataan yang berkaitan dengan penelitian yang dilakukan oleh peneliti.

Pengumpulan data dilakukan selama kurang lebih 45 hari dimulai dari bulan November 2017. Penyebaran kuesioner dilakukan dengan menyebarkan langsung kepada responden dan melalui beberapa contact person kerabat/saudara/teman yang bekerja pada bank di area Jakarta. Selain itu, kuesioner juga disebar secara online melalui google forms yang disebarkan melalui pesan singkat.

\section{Populasi dan Sampel}

Dalam penelitian ini, responden yang berpartisipasi dalam penelitian ini adalah karyawan yang bekerja di bidang akuntansi pada perusahaan perbankan, baik bank syariah maupun bank konvensional, dengan pengalaman kerja kurang lebih 5 tahun di wilayah DKI Jakarta. Provinsi DKI Jakarta dipilih karena mayoritas industri perbankan berpusat di DKI Jakarta. Dari 77 kantor pusat bank swasta, 64 bank diantaranya berpusat di Jakarta dan sisanya di daerah. Adapun target sampel dalam penelitian ini adalah sebesar 125 responden.

Dalam penelitian ini teknik penarikan sampel yang digunakan adalah teknik purposive sampling. Purposive sampling adalah teknik pengambilan sampel sumber data dengan pertimbangan tertentu. Adapun yang dimaksud dengan pertimbangan tertentu dimana responden 
dianggap sebagai orang yang paling tahu tentang apa yang kita harapkan sehingga akan memudahkan peneliti untuk menjelajahi objek atau situasi yang diteliti.

\section{Model Penelitian}

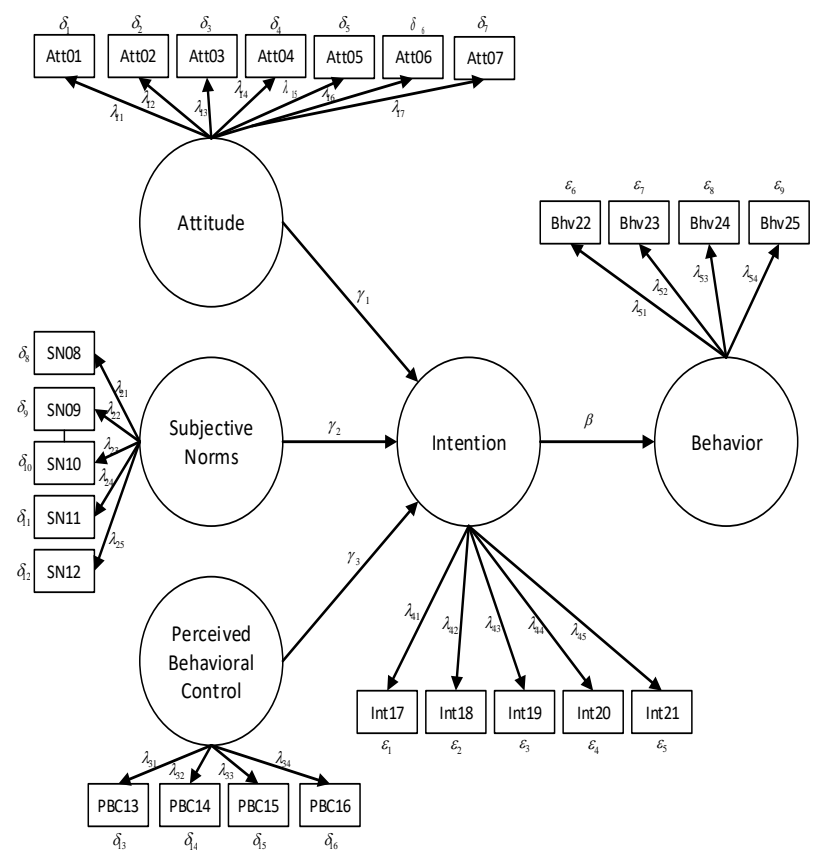

Gambar 3. Model Penelitian

\section{Operasionalisasi Variabel}

Dalam penelitian ini menggunakan kuesioner dengan 25 item pernyataan yang diadopsi dari penelitian Awang dkk. (2015), Carpenter dan Reimers (2005), dan Stone dkk. (2009).

Definisi operasional variabel dalam penelitian ini adalah sebagai berikut:

1. Attitude didefinisikan sebagai evaluasi yang dilakukan seseorang untuk menilai sesuatu secara positif atau negatif terhadap suatu benda, orang, kejadian, perilaku, atau niat tertentu. Variabel ini diukur dengan menggunakan 7 item pernyataan yang diadopsi dari penelitian Stone dkk.., (2009), dengan menggunakan skala likert 4 poin. Skala likert basis 4 digunakan untuk menghindari bias karena jawaban netral.

2. Subjective norms didefinisikan sebagai faktor eksternal yang menunjukkan persepsi seseorang tentang suatu perilaku. Variabel ini diukur dengan menggunakan 5 item pernyataan yang diadopsi dari penelitian Awang dkk., (2015), dengan menggunakan skala likert 4 poin. Skala likert basis 4 digunakan untuk menghindari bias karena jawaban netral.
3. Perceived behavioral control didefinisikan sebagai persepsi atau kemampuan seseorang yang dianggap dapat menghambat untuk melakukan suatu perilaku tertentu. Variabel ini diukur dengan menggunakan 3 item pernyataan yang diadopsi dari penelitian Carpenter dan Reimers (2005), dengan menggunakan skala likert 4 poin. Skala likert basis 4 digunakan untuk menghindari bias karena jawaban netral.

4. Intention didefinisikan sebagai kehendak seseorang untuk melakukan suatu perilaku tertentu. Variabel ini diukur dengan menggunakan 5 item pernyataan yang diadopsi dari penelitian Awang dkk.., (2015), dengan menggunakan skala likert 4 poin. Skala likert basis 4 digunakan untuk menghindari bias karena jawaban netral.

5. Behavior didefinisikan sebagai hasil akhir dari niat individu untuk melakukan suatu perilaku. Variabel ini diukur dengan menggunakan 4 item pernyataan yang diadopsi dari penelitian Stone dkk.., (2009) dengan menggunakan skala likert 4 poin. Skala likert basis 4 digunakan untuk menghindari bias karena jawaban netral.

\section{Metode Analisis Data}

Model yang digunakan dalam penelitian ini merupakan structural equation modelling (SEM). Alat bantu yang digunakan untuk melakukan pengujian dalam penelitian ini adalah LISREL 8.8 full version, karena terdapat lebih dari 15 indikator dalam penelitian ini. Variabel laten dalam penelitian ini terdiri dari 5 variabel laten yaitu: attitude, subjective norms, perceived behavioral control, intention, dan behavior.Variabel teramati yang digunakan dalam penelitian ini berjumlah 25 variabel.Untuk mengukur attitude, ada 7 variabel teramati yaitu Att01, Att02，Att03，Att04，Att05，Att06, Att07. Untuk mengukur subjective norms, ada 5 variabel teramati yaitu SN08, SN09, SN10, SN11, SN12. Untuk mengukur perceived behavior control, ada 4 variabel teramati yaitu PBC13, PBC14, PBC15, PBC16. Untuk mengukur intention, ada 5 variabel teramati yaitu Int17, Int18, Int19, Int20, Int21. Untuk mengukur behavior, ada 4 variabel teramati yaitu Bhv22, Bhv23, Bhv24, Bhv25. Semua variabel teramati dalam penelitian ini diukur dengan skala likert basis 4, yang terdiri dari tingkatan sangat tidak setuju (STS), tidak setuju (TS), setuju (S), dan sangat setuju (SS). Penggunaan skala likert basis 4 ini dilakukan peneliti untuk menghndari bias hasil 
dari jawaban yang bersifat netral.

Pengujian model yang digunakan dalam penelitian ini dilakukan sesuai dengan prosedur analisis structural equation modelling (SEM). Menurut Wijanto (2008), analisis SEM terdiri dari 3 bagian: uji kecocokan model secara keseluruhan, uji kecocokan model pengukuran, dan uji kecocokan model struktural.

Pengujian model dilakukan dengan prosedur analisis SEM. Menurut Yasmin dan Kurniawan (2009), analisis SEM terdiri dari 3 bagian, yaitu:

1. Uji kecocokan model secara keseluruhan (overall model fit)

Berbeda dengan analisis multivariate lainnya, structural equation modelling (SEM) tidak mempunyai uji statistik tunggal terbaik yang dapat menjelaskan kekuatan dalam memprediksi sebuah model. Oleh karena itu kini dikembangkan, beberapa kombinasi uji kecocokan model yang dapat digunakan untuk menjustifikasi apakah model ini baik atau tidak. Ukuran-ukuran uji keseluruhan kecocokan model dilakukan dengan hasil output goodness of fit hasil dari LISREL, dengan kriteria pengujian absolut dan inkremental (Kristanto, 2011).

2. Uji kecocokan model pengukuran (measurement model fit)

Setelah evaluasi terhadap kecocokan keseluruhan model, langkah berikutnya adalah memeriksa kecocokan model pengukuran. Evaluasi model pengukuran dilakukan terhadap masing-masing konstruk laten yang ada di dalam model. Pemeriksaan terhadap konstruk laten dilakukan berkaitan dengan pengukuran konstruk laten oleh variabel manifest (manifest variable atau indikator). Uji kecocokan model pengukuran dilakukan untuk memvalidasi reliabilitas dari konstruk. Dalam pengujian ini akan dihitung construct reliability dan variance extracted dengan rumus sebagai berikut (Kristanto, 2011):

construct reliability

$$
=\frac{\left(\Sigma_{-} \text {std_loading }\right)^{2}}{\left(\Sigma_{-} \text {std_loading }\right)^{2}+\Sigma \varepsilon_{i}}
$$$$
\text { variance extracted } \quad=\frac{\Sigma_{-} \text {std_loading }{ }^{2}}{\Sigma_{-} \text {std_loading }{ }^{2}+\Sigma \varepsilon_{i}}
$$

3. Uji kecocokan model struktural (structural model fit).

Evaluasi tehadap model struktural berkaitan dengan pengujian hubungan antarvariabel tersebut signifikan secara statistik atau tidak. Dalam praktiknya, pengujian biasanya digunakan adalah pengujian dua arah yaitu, menggunakan batas nilai t-statistiknya. Untuk evaluasi keseluruhan persamaan struktural, koefisien determinasi yang digunakan serupa dengan analisis regresi. Nilai koefisien determinasi menjelaskan bahwa seberapa besar variabel eksogen yang dihipotesiskan dalam persamaan mampu menerangkan variabel endogen. Nilai koefisien determinasi yang besar menunjukkan bahwa variabel eksogen mampu menjelaskan variabel endogen.

\section{HASIL DAN PEMBAHASAN}

Demografi Responden

Dalam penelitian ini, objek yang digunakan adalah karyawan yang bekerja di bidang akuntansi pada bank konvensional dan bank syariah dengan pengalaman kurang lebih 5 tahun. Data diperoleh dari penyebaran kuesioner yang menggunakan skala Likert 1-4. Jumlah kuesioner yang disebar sebanyak 186 kuesioner, jumlah yang kembali adalah 182 kuesioner sehingga tingkat pengembalian kuesioner mencapai $97,85 \%$ dari total kuesioner yang dikirim. Terdapat 24 kuesioner dari total kuesioner yang kembali tidak memenuhi kriteria atau tidak lengkap pengisiannya sehingga tidak dimasukkan dalam pengolahan data. Hasil selengkapnya dapat lihat pada tabel 1.

\section{Tabel 1. Rekapitulasi Responden}

\begin{tabular}{|l|l|l|}
\hline & Jumlah & Persentase \\
\hline Kuisioner yang disebar: & 186 & 100 \\
- Fisik & 139 & 74.73 \\
- Online & 47 & 25.27 \\
\hline Tidak kembali & 4 & 2,15 \\
\hline Tidak lengkap & 24 & 12,90 \\
\hline Sampel akhir & $\mathbf{1 5 8}$ & $\mathbf{8 4 , 9 5}$ \\
\hline
\end{tabular}

Dari 158 kuesioner yang dapat dilanjutkan ke pengolahan data, diketahui bahwa 96 responden adalah wanita dan 62 responden pria seperti pada gambar 4. 


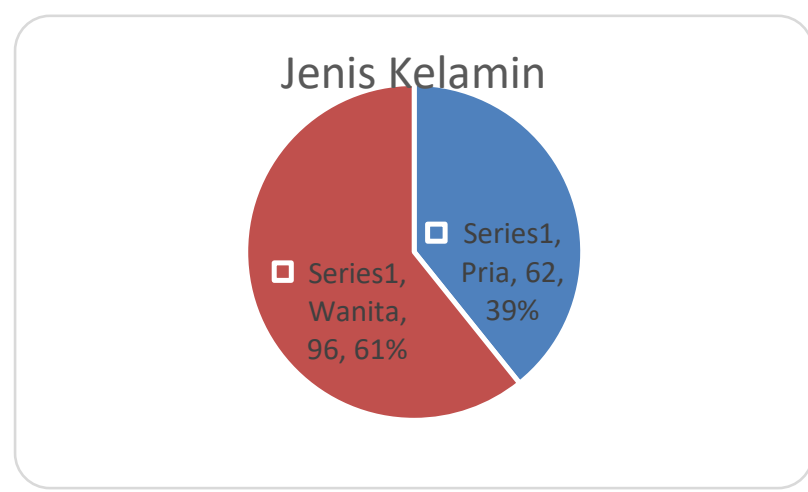

Gambar 4. Demografi Jenis Kelamin Sumber: Data diolah (2018)

Berdasarkan umur, 91 responden berumur kurang dari 30 tahun, 35 responden berumur diantara 3035 tahun, 20 responden berumur diantara 35-40 tahun, dan 12 responden berumur 40 tahun keatas. Ternyata sampel dalam penelitian ini didominasi dengan responden dengan umur dibawah 30 tahun. Data dapat terlihat pada gambar 5.

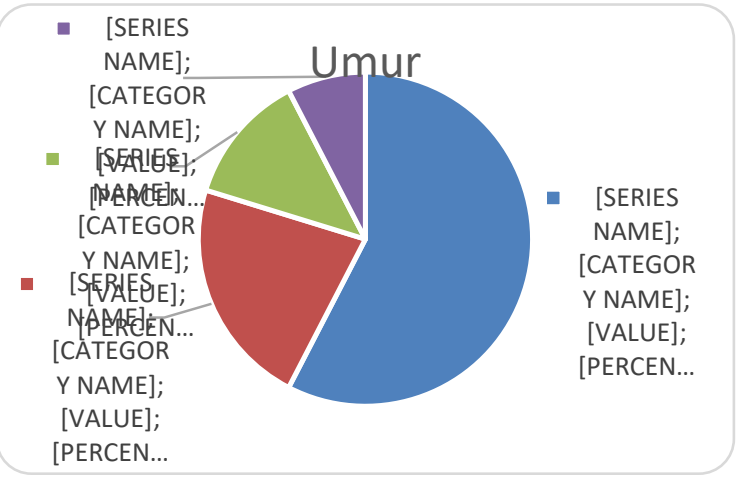

\section{Gambar 5. Demografi Umur} Sumber: Data diolah (2018)

Berdasarkan tingkat pendidikan, 117 responden S1, 13 responden S2, 1 responden S3, dan 27 responden sma/d3. Dalam penelitian ini, sampel didominasi oleh responden dengan tingkat pendidikan di level S1. Data dapat terlihat pada gambar 6 .

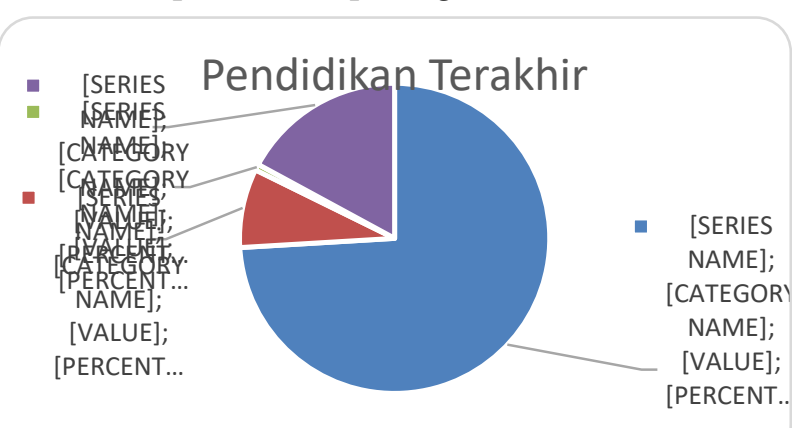

Gambar 6. Demografi Pendidikan Terakhir Sumber: Data diolah (2018)
Berdasarkan pengalaman audit, 98 responden tidak memiliki pengalaman audit, 32 responden memiliki pengalaman audit kurang dari 5 tahun, 20 responden memiliki pengalaman audit diantara 5-10 tahun, 6 responden memiliki pengalaman audit diantara 10-15 tahun, dan 2 responden memiliki pengalaman audit diatas 15 tahun. Data dapat terlihat pada gambar 7 .

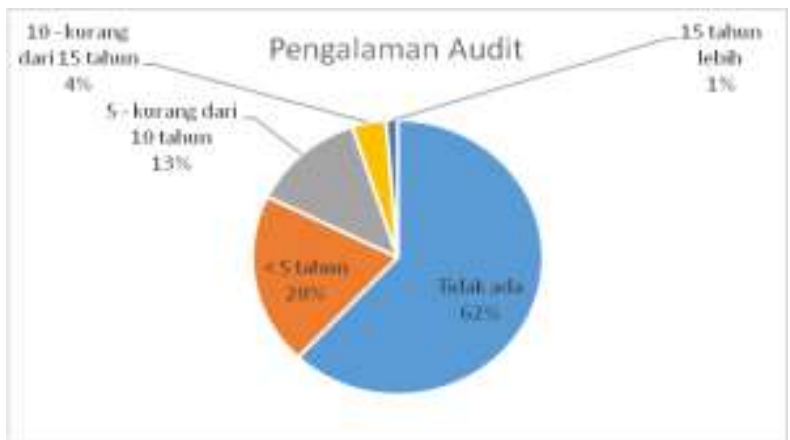

\section{Gambar 7. Demografi Pengalaman Audit} Sumber: Data diolah (2018)

Berdasarkan pengalaman di industri perbankan, 82 responden memiliki pengalaman kurang dari 5 tahun, 45 responden memiliki pengalaman diantara 5-kurang dari 10 tahun, 18 responden memiliki pengalaman 10-kurang dari 15 tahun, dan 13 responden memiliki pengalaman diatas 15 tahun. Data dapat terlihat pada gambar 8.

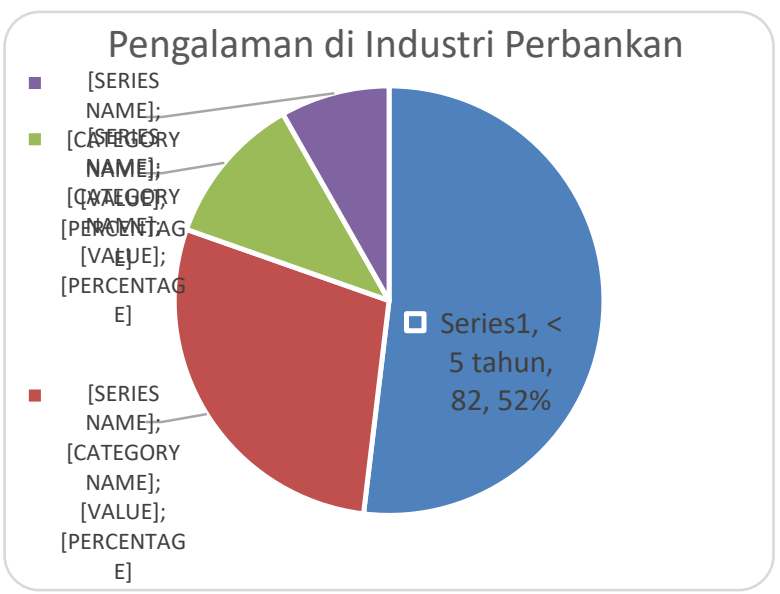

\section{Gambar 8. Demografi Pengalaman di Industri Perbankan}

Sumber: Data diolah (2018)

Berdasarkan pengalaman di tempat kerja saat ini, 98 responden memiliki pengalaman kurang dari 5 tahun, 37 responden memiliki pengalaman diantara 5-kurang dari 10 tahun, 14 responden memiliki pengalaman diantara 10-kurang dari 15 tahun, dan 9 responden memiliki pengalaman lebih dari 15 


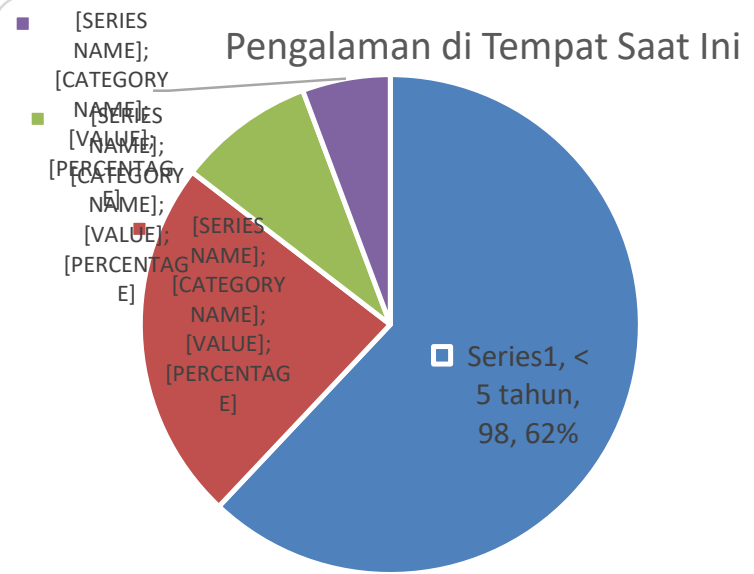

tahun. Data dapat terlihat pada gambar 9.

\section{Gambar 9. Demografi Pengalaman di Tempat Kerja Saat Ini \\ Sumber: Data diolah (2018)}

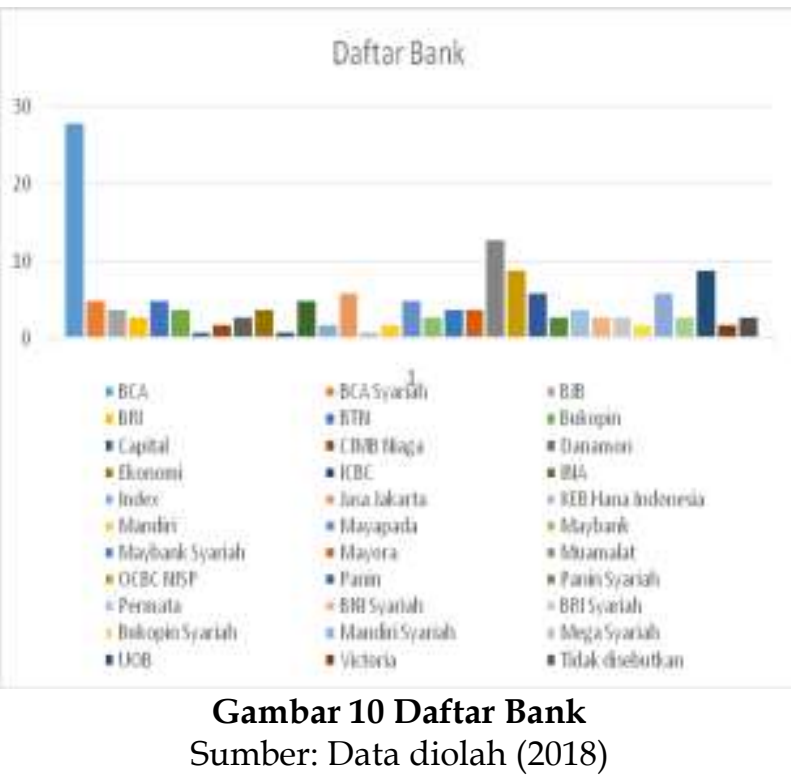

Berikut ini disajikan data bank yang berpartisipasi dalam penelitian ini yaitu, 28 responden bank BCA, 5 responden bank BCA Syariah, 4 responden bank $\mathrm{BJB}, 3$ responden bank BRI, 5 responden bank BTN, 4 responden bank Bukopin, 1 responden bank Capital, 2 responden bank CIMB niaga, 3 responden bank Danamon, 4 responden bank Ekonomi, 1 responden bank ICBC, 5 responden bank INA, 2 responden bank Index, 6 responden bank Jasa Jakarta, 1 responden bank KEB Hana Indonesia, 2 responden bank Mandiri, 5 responden bank Mayapada, 3 responden bank Maybank, 4 responden bank Maybank Syariah, 4 responden bank Mayora, 13 responden bank Muamalat, 9 responden bank OCBC NISP, 6 responden bank Panin, 3 responden bank Panin Syariah, 4 responden bank Permata, 3 responden bank BNI Syariah, 3 responden bank BRI Syariah, 2 responden bank Bukopin Syariah, 6 responden bank mandiri syariah, 3 responden bank Mega Syariah, 9 responden bank UOB, 2 responden bank Victoria, dan 3 responden tidak menyebutkan. Data dapat terlihat pada gambar 10.

Berdasarkan tipe bank, dari 158 kuesioner, sebanyak 116 responden berasal dari bank konvensional dan 42 responden berasal dari bank syariah. Dalam penelitian ini, responden didominasi dari bank syariah. Data dapat terlihat pada gambar 11.

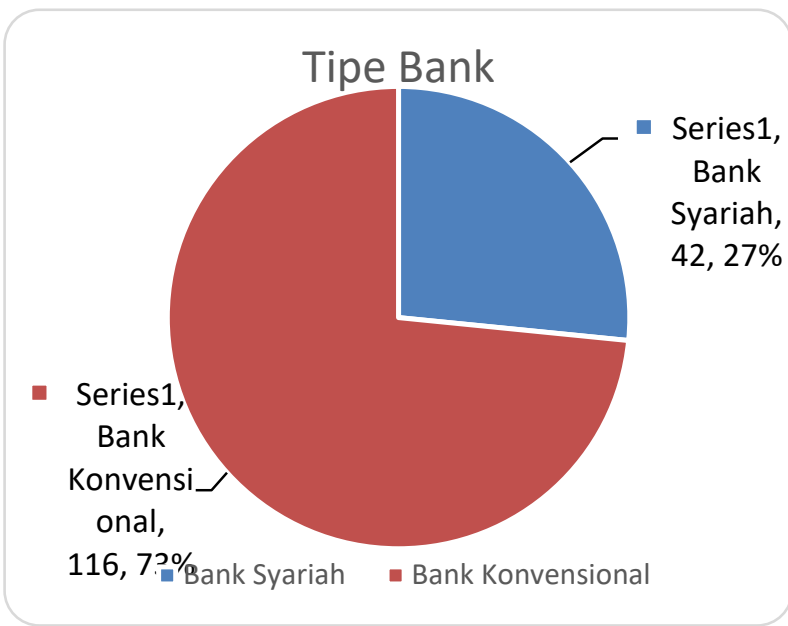

Gambar 11. Tipe Bank

Sumber: Data diolah (2018)

Berdasarkan tipe bank, dari 158 kuesioner, sebanyak 132 responden berasal dari bank lokal dan 26 responden berasal dari bank asing. Dalam penelitian ini, responden didominasi dari bank syariah. Data dapat terlihat pada gambar 12.

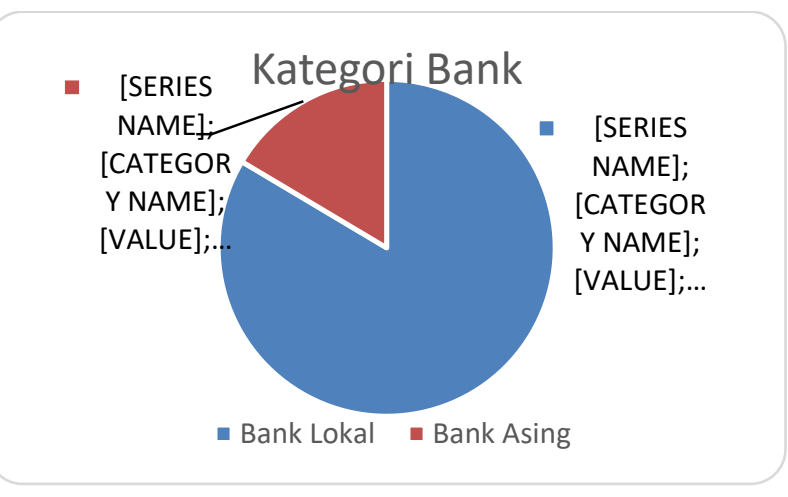

Gambar 12. Kategori Bank

Sumber: Data diolah (2018) 
Hasil Uji Model Secara Keseluruhan (Overall Model Fit)

Penelitian ini menggunakan structural equation modelling (sem) dengan menggunakan alat uji lisrel yang digunakan untuk menguji pengaruh attitude, subjective norms, dan perceived behavioral control terhadap intention untuk melakukan fraud dan menguji intention terhadap behavior untuk melakukan fraud. Hasil dari pengolahan data pada lisrel menunjukkan bahwa attitude, subjective norms, dan perceived behavioral control memiliki pengaruh terhadap intention dan intention memiliki pengaruh terhadap behavior. Hal ini dapat terlihat dari nilai tvalue yang diperoleh dari path diagram seperti ditunjukkan pada gambar 13 .

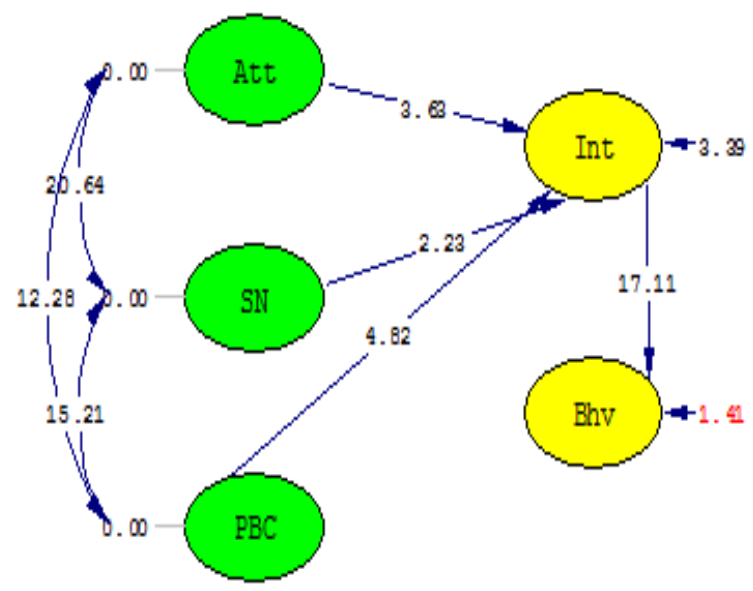

\section{Gambar 13. Path Diagram Model Keseluruhan Sumber: Output Lisrel}

Uji model secara keseluruhan dilakukan dengan melihat hasil analisisnya pada output lisrel yaitu pada ukuran goodness of fit. Nilai dari ukuranukuran goodness of fit dapat terlihat pada tabel 2 . Dari hasil goodness of fit statistics menunjukkan hasil yang cukup baik, namun terdapat kekurangan pada rmsea.
Tabel 2. Hasil Uji Kecocokan Model Keseluruhan

\begin{tabular}{|c|c|c|c|}
\hline $\begin{array}{c}\text { Kriteria } \\
\text { Keco- } \\
\text { cokan } \\
\text { Model }\end{array}$ & $\begin{array}{l}\text { Indikator } \\
\text { Tingkat } \\
\text { Kecocokan }\end{array}$ & $\begin{array}{c}\text { Hasil } \\
\text { Esti- } \\
\text { masi } \\
\text { Model }\end{array}$ & $\begin{array}{c}\text { Tingkat } \\
\text { Keco- } \\
\text { cokan } \\
\text { Model }\end{array}$ \\
\hline RMSEA & $\begin{array}{l}\text { RMSEA < } \\
0.05\end{array}$ & 0.056 & $\begin{array}{l}\text { Kurang } \\
\text { baik }\end{array}$ \\
\hline ECVI & $\begin{array}{ll}\text { Nilai yang } \\
\text { lebih kecil } \\
\text { dari Inde- } \\
\text { pendence } \\
\text { dan lebih } \\
\text { dekat ke Sat- } \\
\text { urated Model }\end{array}$ & $\begin{array}{l}\mathrm{M}^{*}= \\
2.59 \\
\mathrm{~S}^{* *}= \\
3.22 \\
\mathrm{I}^{* * *}= \\
68.76=\end{array}$ & $\begin{array}{l}\text { Baik } \\
\text { (Good Fit) }\end{array}$ \\
\hline AIC & $\begin{array}{lr}\text { Nilai yang } \\
\text { lebih } \quad \text { kecil } \\
\text { dari Inde- } \\
\text { pendence } \\
\text { dan lebih } \\
\text { dekat ke Sat- } \\
\text { urated Model } \\
\end{array}$ & $\begin{array}{l}\mathrm{M}^{*}= \\
406.42 \\
\mathrm{~S}^{* *}= \\
506.00 \\
\mathrm{I}^{* * *}= \\
10794.64\end{array}$ & $\begin{array}{l}\text { Baik } \\
\text { (Good Fit) }\end{array}$ \\
\hline CAIC & $\begin{array}{l}\text { Nilai yang } \\
\text { lebih kecil } \\
\text { dari Inde- } \\
\text { pendence } \\
\text { dan lebih } \\
\text { dekat ke Sat- } \\
\text { urated Model }\end{array}$ & $\begin{array}{l}\mathrm{M}^{*}= \\
637.99 \\
\mathrm{~S}^{* *}= \\
1533.84 \\
\mathrm{I}^{* *}= \\
10884.01\end{array}$ & $\begin{array}{l}\text { Baik } \\
\text { (Good Fit) }\end{array}$ \\
\hline NFI & NFI> 0.90 & 0.97 & Baik \\
\hline NNFI & NNFI $>0.90$ & 0.99 & Baik \\
\hline CFI & CFI> 0.90 & 0.99 & Baik \\
\hline IFI & IFI $>0.90$ & 0.99 & Baik \\
\hline RFI & RFI> 0.90 & 0.97 & Baik \\
\hline RMR & $\begin{array}{l}\text { Standardized } \\
\mathrm{RMR}<0.05\end{array}$ & 0.047 & Baik \\
\hline GFI & $\begin{array}{l}\text { GFI > }>0.90, \\
\text { good fit; } 0.90< \\
\text { GFI > } 0.80, \\
\text { marginal fit }\end{array}$ & 0.86 & $\begin{array}{l}\text { Cukup } \\
\text { Baik (Mar- } \\
\text { ginal Fit) }\end{array}$ \\
\hline
\end{tabular}

Hasil Uji Kecocokan Model Pengukuran (Measurement Model Fit)

Uji kecocokan model pengukuran dilakukan dengan dua cara yaitu menggunakan uji reliabilitas dan uji validitas. Uji reliabilitas dilakukan dengan menghitung construct reliability dan variance extracted dari masing-masing variabel teramati. Kriteria untuk construct reliability yaitu loading factor nya lebih besar dari 0.70 sedangkan untuk variance extracted, loading factor nya lebih besar dari 0.50. Nilai-nilai tersebut diambil dari angka-angka yang ada pada output completely standardized solution dari hasil pengolahan data. Ringkasan 
hasil perhitungan reliability construct dan variance extracted dapat terlihat pada tabel 3.

Tabel 3. Hasil Uji Model Pengukuran

\begin{tabular}{|c|c|c|c|}
\hline $\begin{array}{c}\text { Variabel } \\
\text { Laten }\end{array}$ & $\begin{array}{c}\text { Construct- } \\
\text { Reliability } \\
\text { Nilai } \\
>=0.70\end{array}$ & $\begin{array}{c}\text { Variance- } \\
\text { Extracted } \\
\text { Nilai } \\
>=0.50\end{array}$ & $\begin{array}{c}\text { Kes- } \\
\text { impulan }\end{array}$ \\
\hline Attitude & $\begin{array}{l}0.70446336 \\
1\end{array}$ & $\begin{array}{l}0.58802816 \\
9\end{array}$ & Baik \\
\hline $\begin{array}{l}\text { Subjective } \\
\text { Norms }\end{array}$ & $\begin{array}{l}0.86333084 \\
3\end{array}$ & $\begin{array}{l}0.65009560 \\
2\end{array}$ & Baik \\
\hline $\begin{array}{l}\text { Perceived } \\
\text { Behavior- } \\
\text { al Control }\end{array}$ & $\begin{array}{l}0.74507042 \\
2\end{array}$ & $\begin{array}{l}0.55961070 \\
5\end{array}$ & Baik \\
\hline Intention & $\begin{array}{l}0.96461029 \\
5\end{array}$ & $\begin{array}{l}0.86019417 \\
4\end{array}$ & Baik \\
\hline Behavior & 0.918489 & $\begin{array}{l}0.77136258 \\
6\end{array}$ & Baik \\
\hline
\end{tabular}

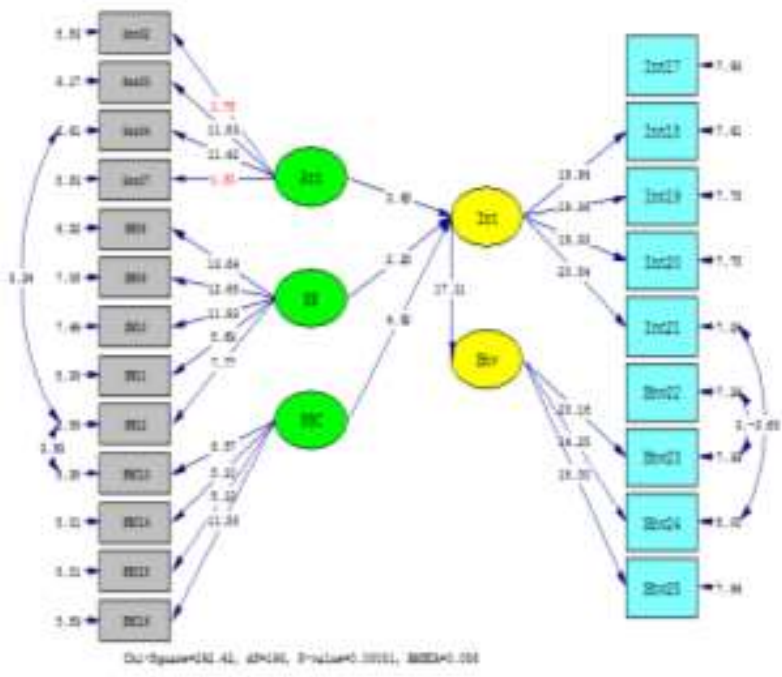

Gambar 14. Path Diagram Model Pengukuran Sumber: Output Lisrel (2018)

Selanjutnya uji validitas yang merupakan pengujian terhadap 25 item pernyataan pada kuesioner yang disebar. Hasil pengujian menunjukkan terdapat 3 item pernyataan tentang variabel Attitude yang tidak memenuhi nilai validitas yang baik. Pernyataan tersebut adalah pernyataan Att01, Att05, dan Att06, hal ini dapat terlihat dari nilai tvalue masing-masing pernyataan sebesar 1.45, 0.67, dan 1.20 dimana ketiganya lebih kecil dari 1.96 . Oleh karena itu, ketiga pernyataan tersebut sebaiknya tidak dimasukkan untuk penelitian lebih lanjut. Secara lengkap nilai t-value dari masingmasing pernyataan dapat terlihat dari gambar Path Diagram yang ada pada Gambar 14.
Hasil Uji Kecocokan Model Struktural (Structural Model Fit)

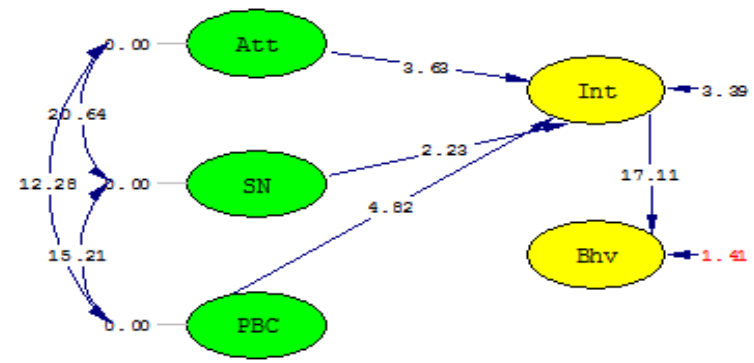

Gambar 15. Path Diagram Model Struktural Sumber: Output lisrel (2018)

Dalam melakukan penilaian terhadap coefficient of determination dari persamaan struktural, dapat terlihat dari besaran $\mathrm{R}^{2}$. Nilai $\mathrm{R}^{2}$ diperoleh dari hasil pengujian LISREL yang dapat terlihat dari Reduced Form Equation. Pada penelitian ini, nilai $\mathrm{R}^{2}$ untuk variabel Intention sebesar 0.92 yang berarti model ini mampu menjelaskan $92 \%$ dari perubahan pada variabel Intention. Jadidapat disimpulkan bahwa dari uji ini menunjukkan model yang sangat baik dalam merepresentasikan hubungan variabel Attitude, Subjective Norms, dan Perceived Behavioral Control dengan variabel Intention, sehingga $\mathrm{H}_{1}, \mathrm{H}_{2}$, dan $\mathrm{H}_{3}$ diterima.

Kemudian untuk variabel Behavior, nilai $\mathrm{R}^{2}$ didapat sebesar 0.89 yang berarti model ini mampu menjelaskan $89 \%$ dari perubahan pada variabel Behavior. Jadi dapat disimpulkan bahwa dari uji ini menunjukkan model yang sangat baik dalam merepresentasikan hubungan variabel Intention dengan variabel Behavior, sehingga $\mathrm{H}_{4}$ diterima.

\section{$\frac{\text { Pembahasan }}{\text { Penti }}$}

Penelitian ini bertujuan untuk menguji pengaruh attitude, subjective norms, dan perceived behavioral control terhadap intention, dan menguji pengaruh intention terhadap behavior untuk melakukan fraud laporan keuangan. Setiap variabel dalam penelitian ini diukur dengan menggunakan pernyataan dalam kuesioner yang diadopsi dari penelitian Awang dkk. (2015), Stone dkk. (2009) serta Carpenter dan Reimers (2005).

Setelah melakukan pengujian, hipotesis pertama dalam penelitian ini yaitu attitude memiliki pengaruh positif terhadap intention untuk melakukan fraud, terbukti signifikan secara statistik. Hasil penelitian ini mendukung hasil penelitian sebelumnya yaitu Carpenter dan Reimbers (2005) dan Stone dkk. (2009). Setiap responden yang bersikap menentang fraud, salah satunya pada item kueisoner Att03 yaitu "Saya mengizinkan orang 
lain untuk melakukan fraud" menunjukkan niat yang rendah pula untuk melakukan fraud. Pada penelitian ini, responden yang memiliki sikap menentang fraud menunjukkan niat yang rendah untuk melakukan fraud. Niat yang rendah akan mempengaruhi perilaku individu untuk tidak melakukan fraud. Sehingga dapat dikatakan bahwa attitude berpengaruh positif terhadap intention untuk melakukan fraud.

Hipotesis kedua yaitu subjective norms memiliki pengaruh positif terhadap intention untuk melakukan fraud, terbukti signifikan secara statistik. Hasil penelitian ini mendukung penelitian sebelumnya yaitu Winahjoe dan Sudiyanti (2014), Carpenter dan Reimbers (2005) dan Stone dkk. (2009). Hasil ini menunjukkan adanya peran orangorang disekitar para karyawan perbankan dalam mempengaruhi niat individu untuk melakukan atau tidak melakukan fraud.

Hipotesis ketiga yaitu perceived behavioral control memiliki pengaruh positif terhadap intention untuk melakukan fraud, terbukti signifikan secara statistik. Hasil penelitian ini mendukung penelitian sebelumnya yaitu, Rustiarini dan Sunarsih (2015) dan Stone dkk. (2009). Sebagai contoh, jika responden menentang itemkuesioner PBC15 "Jika saya ingin, saya dapat dengan mudah melakukan fraud dalam laporan keuangan" dapat menunjukkan kontrol atas perilaku yang kuat. Bagi karyawan perbankan yang ingin melakukan fraud biasanya didasari oleh kesempatan dan kendali yang ia miliki. Oleh karena itu, semakin kuat kendali perilaku yang dirasakan oleh individu, maka semakin besar niat untuk melakukan fraud. Sebaliknya, jika kontrol perilaku lemah, maka niat untuk melakukan fraud semakin kecil.

Hipotesis keempat yaitu intentionmemiliki pengaruh positif terhadap behavior untuk melakukan fraud, terbukti signifikan secara statistik. Hasil penelitian ini mendukung penelitian sebelumnya yaitu stone dkk. (2009). Perilaku fraud didasari oleh niat untuk melakukannya. Oleh sebab itu, semakin besar niat seorang individu untuk melakukan fraud, maka semakin besar juga peluang individu untuk melakukan fraud.

\section{SIMPULAN}

Berdasarkan hasil pengujian dan pembahasan sebagaimana telah disajikan pada bab sebelumnya, maka dapat ditarik beberapa kesimpulan. Ketiga variabel yaitu attitude, subjective norms, dan perceived behavioral control terbukti mempengaruhi intention dalam melakukan fraud laporan keuangan. Walapun industri perbankan termasuk salah satu industri dengan regulasi yang ketat, ternyata tidak menutup kemungkinan adanya pihak-pihak yang ingin melakukan tindakan fraud. Intention yang tinggi ternyata mendasari individu untuk melakukan tindakan fraud. Sehingga dapat dikatakan bahwa perilaku untuk melakukan fraud dipengaruhi oleh niat atau keinginan individu. Dalam penelitian ini, jika responden menyatakan keinginannya untuk melakukan fraud maka responden cenderung menyetujui perilaku untuk melakukan fraud. Jika dibandingkan dengan penelitian sebelumnya yang dilakukan oleh Awang dkk. (2015) yang menggunakan Theory of Reasoned Action untuk mengukur potensi fraud di industri perbankan di Malaysia, Theory of Planned Behavior dinilai telah berhasil menjelaskan perilaku fraud di industri perbankan di Indonesia dengan baik. Kedua teori tersebut dapat dinyatakan relevan untuk digunakan dalam menganalisis perilaku individu.

Penelitian ini masih memiliki beberapa keterbatasan. Oleh karena itu, adapun beberapa saran yang dapat digunakan oleh peneliti selanjutnya yang ingin melanjutkan penelitian ini, yaitu variabel yang ada didalam penelitian ini hanya mengadopsi konsep theory of planned behavior. Sebaiknya peneliti selanjutnya dapat menambah variabel lain, misalnya religiosity. Adapun bank yang berpartisipasi dalam penelitian ini masih tergolong minim, sebaiknya peneliti selanjutnya menambah variasi bank yang berpartisipasi dalam penelitian ini dengan meningkatkan penyebaran pada bank asing dan bank syariah. Peneliti selanjutnya dapat mencoba menjadikan tipe bank sebagai variabel kontrol.

\section{REFERENSI}

Association of Certified Fraud Examiners, (2016), Global Fraud Survey: Report to the nation on occupational fraud and abuse: Association of Certified Fraud Examiner.

Ajzen, I., (1991), The Theory of Planned Behavior, Organizational Behavior and Human Dicision Process, Vol 50, page 179-211.

Awang, Y., Ismail, S., dan Rahman, A. R. A., (2015), Measuring The Potential for Financial Reporting Fraud in a Highly Regulated Industry. Asia Pacific Conference on Accounting and Finance in Bali - Indonesia.

Carpenter, T. D., dan Reimers, J. L. (2005), Unethical and fraudulent financial reporting: Applying the theory planned behavior. Journal of Business Ethics, Vol 60 
No 2, page 115-129.

Haniffa, R., dan Hudaib, M., (2007), Exploring the ethical identity of islamic banks via communication in annual reports, Journal of Business Ethics, Vol 76 No 1, page 97-116.

Hays, J. B., (2013), An Investigation of the motivation of management accountants to report fraudulent accounting activity: applying the theory of planned behavior, Doctoral Dissertation, H. Wayne Huizenga School of Business and Entrepreneurship, Nova Southeastern University.

Kristanto, S.B., (2011), Structural equation modeling (SEM) menggunakan MX dan LISREL. Publikasi internal UKRIDA

More, I., (2012). Malinda Dee Divonis 8 Tahun Penjara. Diunduh dari kompas.com:http://megapolitan.kompas.c om/read/2012/03/07/14183725/Malinda. Dee.Divonis.8.Tahun.Penjara

Rustiarini, N. W., dan Sunarsih, N. M., (2015), Fraud and Whistleblowing: Pengungkapan kecurangan akuntansi oleh auditor pemerintah. Simposium Nasional Akuntansi ke-18, Medan - Sumatera Utara.

Siti, M. N. H., Idris, K. M., Rahman, R. A., dan Wah, Y. B. (2011). Antecedents of non-normal financial reporting. International Journal of Business and Science, Vol 2 No 5, page 170178.

Stone, T. H., Jawahar, I., dan Kisamore, J. L., (2009), Using the theory of planned behavior and cheating justifications to predict academic misconduct, Career Development International, Vol 14 No 3, page221-241.

Wijanto, S. H., (2008), Structural Equation Modeling dengan Lisrel 8.8. Yogyakarta: Graha Ilmu.

Winahjoe, S., dan Sudiyanti, (2014), Predicting intended unethical behavior among college of economics and business studens: an empirical study at Universitas Gadjah Mada, Journal of Indonesian Economy and Business, Vol 29 No 1, page 31-43.

Yamin, S., dan Kurniawan, H., (2009), Structural Equation Modeling, Jakarta: Salemba Infotek. 